\title{
THE EFFECT OF CASH FLOWS OF OPERATION AND LIQUIDITY ON PROFITABILITY: A STUDY IN PROCESSING AND MANUFACTURING INDUSTRY SECTOR'S COMPANIES IN PT BANK BRISYARIAH, TBK
}

\author{
Bobihoe Arjanto*, Syah Tantri Yanuar Rahmat, Anindita Rina \\ Faculty of Economics and Business, University of Esa Unggul, Indonesia \\ *E-mail: abobihoe99@gmail.com
}

\begin{abstract}
This study aims to determine the effect of operating cash flow as measured by AKO and liquidity as measured by the current ratio to profitability as measured by return on equity in the Manufacturing companies on the PT BRISyariah, Tbk. Data used in this research is secondary data, i.e. annual financial statements in 2014 until 2017 while the samples used in this study was determined by clustered sampling method, so that the company obtained 6 samples. The analytical method used is descriptive analysis by describing the tables of Cash Flow Ratio (Operating Cash Flow), Liquidity (Current Ratio) and Profitability (Return on Equity) and inferential analysis using multiple regression analysis. The results of this study concluded: (1) Operating cash flow has a positive and significant impact on profitability with a significance level of $0.013<0.05$, (2) liquidity has a negative influence but not significant to profitability with a significance level of $0.254>0.05$.
\end{abstract}

\section{KEY WORDS}

Operating cash flow, liquidity, profitability, industry.

A company's financial statements are an important medium in the economic decisionmaking process. In principle, financial statements are information that can help managers, creditors and investors in interpreting the performance of a company. One important part of financial statements is the cash flow statement.

Cash is the most current element of assets, or in other words cash is the most liquid working capital, so that with sufficient cash available, the company will not have any difficulties in fulfilling the obligations that are due. Every company needs cash to carry out its operations, such as buying raw materials, paying wages and salaries, paying off short-term obligations and distributing dividends to shareholders. The Management in order to improving the company's financial structure, is responsible in maintaining the company's liquidity to create profitability in the company's operational activities. The Management should trying to increase revenue or business profits to finance all company activities. The management must determine the amount of cash available so that the company is able to fulfill its obligations when it is due, because cash shortages are the initial symptom of possibility bankruptcy company. The success of a company in managing finances will support it in maintaining and developing its business and being able to compete with competitors and obtain the profits the company wants to achieve.

The Management in determining and assessing the level of liquidity and profitability of the company, in addition to requiring balance sheet information and income statement, also requires other financial information, namely cash flow statements.

The research results of Rena Kurniawati (2012) found that net cash flow had a significant effect on liquidity, the magnitude of the effect of cash flow and liquidity simultaneously had no significant effect on profitability. Wael Mostafa (2015) found that income and cash flows have relevance to each other. While Erni Nuraeni (2011) found that cash flow has a strong positive relationship to profitability and working capital has a low negative relationship to profitability, but simultaneously Cash Flow and Working Capital have a significant effect on profitability. The results of Anggi Maharani's study (2010), cash flow does not significantly influence the level of profitability of the company in terms of Net Profit Margin. While the results of Shopi Guspiati (2008) study show that the LTA variable ( ratio of 
liquid assets to total assets) has a positive and significant effect on profitability, LAD (ratio of liquid assets to deposits) has a negative and significant effect on profitability, and FDR (ratio of financing to deposits) does not have a significant effect on profitability, but simultaneously the independent variables influence the dependent variable. While the research results of Sri Nurdianti (2013), show that liquidity has a significant negative effect on profitability. The results of the study by Inta Budi Setyanusa (2013) show that Liquidity has a significant positive effect on profitability. The findings of Sutarti and Adi Sulaeman (2011) show that Operating Cash Flow has a significant influence on Net Profit generated by the company.

The findings of Khemala Febriani Mardhika (2012), show that simultaneously da $n$ partial Inventory Turnover and Cash Flow (Operating Cash Flow) b erpengaruh significant to profitability (ROA). The findings of Lisna Riany Silaen (2012) shows that The current ratio have that real effect on ROA and ROE. Findings of Defri (2012), to show that Influential CAR positive and not significant to ROA, Influential LDR positive and not significant to ROA, and influential BOPO has negative efect and significant to ROA at banking companies listed on the IDX. The problem of this research can be identified as follows:

(1) How is the influence operating cash flow against profitability company and, (2) How is the influence of liquidity to profitability company.

\section{LITERATURE REVIEW}

Skousen (2009: 284), defines: "Cash flow statement ( statement of cash flow) is a financial report that reports the amount of cash received and paid by a company for a certain period". Sofyan Syafri Harahap (2010: 257), argues that "Cash flow reports provide relevant information about cash receipts and expenditures of a company in a given period, by classifying transactions in activities: operations, funding and investment". (Jaworski and Czerwonka 2016) argued that "there is a significant relationship between profitability and liquidity of companies listed on the Warsaw stock exchange. The positive impact is on the profitability of the company's capacity and negatively impacts the company's debt. So, the bigger the company, the greater the profitability. The greater the involvement in debt, the lower the profitability.

Current cash report that used in this study are Cash Flow from Operating Activities. Cash flows from operating activities is on indicators that are determine is from its operation company can produce cash that can be used to pay off loans, maintain ability operation company, pay dividends and do investment $b$ aru without relying on external funding sources. So that current cash operating activities could to be signal for investors regarding the condition of the company. "Current Cash Operation ( operating activities ) include cash generated and issued in determination of determining net income. Cash flows from operating activities include cash flows arising from the delivery or production of goods for sale and the provision of services, as well as the effects of transactions and other events on cash that affect income "(Suriani ginting, 2012).

PSAK No. 2 paragraph 12 (IAI: 2012) states that: The amount of cash flows originating from operating activities is the main indicator to determine whether the entity's operations can generate sufficient cash flows to repay loans, maintain the entity's operating capabilities, pay dividends and make new investments without relying on outside funding sources. Information about certain elements of historical cash flows along with other information is useful in predicting future operating cash flows. In general, the cash flow comes from transactions and other events that affect the determination of profit or loss clean.

Liquidity is one of the important financial aspects to analyze because liquidity is one of tools that can be used to measure the success of a company as seen from how much the company's ability to fulfill its current obligations. "Liquidity is the company's ability to fulfill obligations that are due" (Agnes Sawir, 2005). Munawir (2007: 31) argues that: "liquidity indicates the ability of a company to fulfill its financial obligations that must be fulfilled immediately, or the company's ability to fulfill financial obligations when billed". Sutrisno (2009: 215) define, "Liquidity is the company's ability to pay its obligations that are immediately fulfilled". 
Safdar (2015) argues that: "Positive and significant liquidity has a relationship with profitability".

A company can be said to be liquid if the company is able to pay off short-term financial obligations and long-term obligations that are due in the year concerned. Conversely, if a company is not able to pay off its financial obligations are classified into the company liquid.

The liquidity ratio used in this study is the Current Ratio. Sutrisno (2009: 216) revealed that, " Current Ratio is a ratio that compares the current assets that have a company with short-term debt. Current assets include cash, accounts receivable, securities, inventories and other current assets. While short-term debt includes trade payables, notes payable, bank loans, salary debt and other debts that must be paid immediately".

This current ratio shows the level of short-term creditor security or the company's ability to pay off these debts. But a company with a high current ratio does not necessarily guarantee that it will be able to pay company debt due because the proportion or distribution of current assets is not profitable.

The main goal for companies is to get optimal profits. Nevertheless the problem of profitability is more important than the problem of profit, because large profits are not yet a measure for the company has worked efficiently. New can be efficient known by comparing the company's operating profit or in other words is calculating its profitability. "Profitability is the company's ability to generate profits. Profitability shows the success of a business entity in generating returns to the owner " (Sofyan Syafri Harahap, 2010). Sutrisno (2009) defines: "Profitability is the result of the wisdom taken by management. The profit ratio to measure how much the profit level shows is better management in managing a company. "Brigham and Houston (2010), put forward that: " profitability is the end result from a number of policies from decisions made by the company. Ratios that have been discussed so far it can provide useful clues in assessing the effectiveness and operation of a company, but the profitability ratio will show a combination of effects of liquidity, asset management, and debt on operating results. Munawir (2007), explained that "Profitability is a ratio used to assess a company's ability to make a profit".

Return On Equity (ROE) is one of the profitability ratios used to measure the company's ability to make profits based on capital (Houston and Brigham, 2010). The greater the ratio, the greater the increase in the net profit of the company concerned, then it will increase the company's stock price and the greater the dividends received by investors. ROE is a very important indicator for shareholders and prospective investors to measure the company's ability to obtain net income associated with dividend payments. PSAK No. 21 paragraph 03 (IAI: 2012) states that: "Basically equity comes from the owner's investment and results business company. Equity will decrease especially with the withdrawal of ownership by the owner, profit sharing or due to losses. In PSAK No. 21 paragraph 04 (IAI: 2012) stated that: "Equity consists of the owner's deposit which is often called capital or principal savings of members for cooperative legal entities, retained earnings, and other elements. Sutrisno (2009) stated that, " Return on equity is often referred to as the rate of return on net worth, which is the ability of companies to generate profits with their own capital, so that there is ROE that refers to the profitability of their own capital. This ratio shows the ability of owner's capital invested by the owner or investor to generate net income which is part of the owner. The higher the ratio, the higher the investor's profit because the more efficient the capital is invested. Thus, this ratio is used to measure the ability of own capital for generate profits for all shareholders, both ordinary shares and preferred shares".

Cash has a very important role in the continuity of company activities, so that special attention is needed in its management special ones. Poor cash management can cause cash operations to be less effective. Companies that are able to generate sufficient cash from their operating activities are likely to have a sound financial condition because they do not depend on funding sources from outside the company. A healthy company will be able to fulfill its term obligations in short.

In addition to operating cash flow and liquidity, profitability is one of the important things in the company. The success or failure of a company in carrying out its business, can be 
seen from the level of profit obtained by a company. In this case whether the operating cash flow and liquidity can have an effect on profitability.

The hypothesis can be formulated in this study:

$\mathrm{H} 1$ : Operating cash flow has a positive effect on profitability;

$\mathrm{H} 2$ : Liquidity has a positive effect on profitability.

\section{METHODS OF RESEARCH}

The population observed in this study is a Manufacture companies customer at PT Bank BRISyariah, Tbk with a population of 20 companies. The sample in this study are 6 companies engaged in the Processing Industry (Manufacturing) and the selection of samples using Clustered Sampling, which is the selection of samples based on certain groups or clusters. The Criteria to be used is to classify similar companies and have audited financial statements for 2014 - 2017, with the criteria that such companies have the positive operating cash flow conditions and profitability positive.

The data obtained in this study are secondary data (financial statements) of companies engaged in the Processing Industry (Manufacturing). The analysis technique used in this study is: Descriptive Analysis and Inferential Analysis using multiple regression analysis techniques using the formula J. Supranto (2014):

$$
Y=\beta_{0}+\beta 1 X_{1}+\beta 2 X_{2}+\ldots+\beta_{n} X_{n}+\text { is }
$$

To test significancy two tests were carried out, namely: $F$ test (model test) and hypothesis testing using t-test.

\section{RESULTS AND DISCUSSION}

From the 6 companies engaged in the Manufacturing Industry (Manufacturing) sector which are customers at PT Bank BRISyariah, Tbk, only 2 companies which have cash flows and have a positive trend, namely PT Pindo Deli Pulp Paper and PT Bio Farma. PT Pindo Deli Pulp Paper has a trend of positive cash flow and has increased by Rp 239 trillion in Des Bucket 2014 to become Rp 356 trillion De position as of 20 17. Then for PT Bio Farma also has a positive but declining operating cash flow trend which is amounting to Rp 613 trillion in the position of the Des bucket 2014 becomes IDR 105 Trillion Des bucket position 2017. Thus have good abilities in fulfill the company's operational activities, such as payment of taxes, payments employee salaries, interest payments, and fulfillment of operational activities others.

The level of liquidity of these 6 companies is in good condition, this is due to the condition of the company's liquidity in a positive value with an average of $146.91 \%$. From the 6 companies engaged in the Manufacturing Industry (Manufacturing) sector in PT Bank BRISyariah, the largest liquidity is PT Bio Farma, with a percentage of $302.81 \%$. This is because the current assets owned by the company have a very large value of Rp. 1.75 trillion compared to the current debt owned by the company, which is only Rp. 686 billion, although the company's operating cash flow is very small, but the company obtains a substantial loan some of which are also used to repay loans both long-term and short-term loans, with the amount of cash flows obtained from funding activities, so that the funds used by companies to cover current liabilities come from other activities, namely cash flows from financing activities. In addition, current assets owned by the company are sufficient big.

The level of profitability owned by 6 companies has varied values. The average profit achieved by the company is amounting to $18.02 \%$. The company that can achieve the highest profit among the 6 companies is PT Sinar Agung Always Success (SASS) which is equal to $44.88 \%$ where profit after tax is Rp 111 billion. This is because the company's operating cash flow is quite good and its liquidity is very good at $121.82 \%$ so that it can be seen that the company's operations are in good condition and can fulfill its short-term obligations very well. 
The data normality test results show the significance values obtained from the Kolmogorov-Smirnov One-Sample test of 0.16 greater than the $5 \%(0.05)$ slope rate, so it is concluded that the regression model is normally distributed. The multicollinearity test results found that the value of Variance Inflation Factors (VIF) operating cash flow and liquidity of 1.320 is still smaller than 9 and greater than 1 so that it can be concluded that there is no multicolonity between the two independent variables. The autocorrelation test is used to obtain the Durbin-Watson $(\mathrm{DW})=1.654$ statistical value because the Durbin-Watson regression model (1.654) is between dU (1.5464) and 4-dU (2.4536), which is an area where there is no positive autocorrelation or negative, it can be concluded that there is no autocorrelation in the regression model. Heterocedasticity test shows the significance value of each correlation coefficient of the two independent variables with absolute error (RES2) which is 0.379 and 0.414 is still greater than 0.05 . hetero.

The results of the multiple regression equation in this study, $Y=0.218+0.065 X_{1}-$ $0.0021 \mathrm{X}_{2}$. This means that every increase in operating cash flow by $100 \%$, it is predicted to increase the company's profitability by $6.5 \%$ assuming constant company liquidity and every increase in liquidity by $100 \%$, it is predicted to decrease the company's profitability by $0.2 \%$ with cash flow assumptions constant company operations and a constant value of 0.218 or $21.8 \%$ indicate the predicted value of the company's profitability if the cash flow statement and liquidity are the same as zero.

Test model ( $F$ statistic test) shows that the coefficient of determination or $R$ square is $0.487 \%$ and significant value is $0.021<0.05$, which means that the regression model is feasible. Hypothesis testing the effect of operating cash flow on profitability shows that the regression coefficient is 0.065 and the significance value of operating cash is $0.013<\alpha=$ 0.05 means that it can be concluded that operating cash flows have a positive and significant effect on profitability in companies engaged in the industrial sector Processing (Manufacturing) at PT Bank BRISyariah, Tbk. Direction marked positive effect shows that if the cash flow the company increased the profitability will increase and vice versa. These results are in accordance with the findings of Erni Nuraini (2011) and Khemala Febriani Mardhika (2012), but not in accordance with the findings of Anggi Maharani (2010) and Sutarti and Adi Sulaeman (2011). The hypothesis test of the effect of liquidity on profitability shows that the regression coefficient of -0.0021 and the significance value of liquidity of 0.025 means that liquidity has a negative but not significant effect on profitability in companies engaged in the Manufacturing Industry (PT) BRISyariah, Tbk. The results are in accordance with the findings of Sri Nurdianti (2013), Shopi Guspiati (2008), but not in accordance with the findings of Inta Budi Setyanusa (2013) and Lisna Riany Silaen (2012).

\section{CONCLUSION AND SUGGESTIONS}

This study can be concluded as follows: Average Operating Cash Flow (AKO Ratio) owned by 6 companies engaged in the Manufacturing Industry (Manufacturing) sector in PT Bank BRISyariah, Tbk, which is quite low at $22.65 \%$, this means 77 , The remaining $35 \%$ consists of other activities used to cover the company's current liabilities.

The average level of liquidity ( Current Ratio) of 6 companies engaged in the Manufacturing Industry (Manufacturing) sector in PT Bank BRISyariah, Tbk is quite good at $146.91 \%$, which means that current assets owned by the company can meet company shortterm obligations. The average profitability (Return on Equity) obtained by 6 companies engaged in the Manufacturing Industry (Manufacturing) sector in PT Bank BRISyariah, Tbk for the period $2014-2017$ is $18.02 \%$. Operating and liquidity cash flows can explain profitability of $48.7 \%$, while the remaining $51.3 \%$ is explained by other variables not examined. The operating cash flow has a positive and significant effect on profitability in 6 companies engaged in the Manufacturing Industry (Manufacturing) sector. at PT Bank $B R I S y a r i a h$, Tbk. Liquidity has a negative but not significant effect on profitability in 6 companies engaged in the Manufacturing Industry (Manufacturing) sector at PT Bank BRISyariah, Tbk. 
For further research, namely (1) Dividing and extending the study period in a semester so that it can see trends that occur in the long term so that it will describe the actual conditions that occur, (2) The ratio used to measure independent variables does not only consist of two ratios, so the results obtained can be better and more spacious than the current study and (3) may use other independent variables that affect the profitability of a company, such as the Working Capital, Net Cash Flow, Cash Flow of activity Financing, Cash Flow of activity Investments, Solvency, Operational Costs, Capital Turnover, and others so.

\section{REFERENCES}

1. Agnes Sawir. 2005. Financial Performance Analysis and Financial Planning Company. Jakarta: PT Gramedia Library Main.

2. Anggi Maharani. 2010. Effect of Cash Flow to Level of Profitability Company. Essay. Indonesian Computer University.

3. Brigham, Eugene F., and Joel F., Houston. 2010. Financial Management. Book 1, Edition VIII. Jakarta: Erlangga Publisher.

4. Scientific and Financial Bulletin of Banking Vol. 6 No.1, 2013. Analysis of Cash Flow Ratios for Measuring Performance Finance.

5. Darsono and Ashari, 2005. Practical Guidelines for Understanding Financial Reports, Andy, Yogyakarta.

6. Defri. 2012. Effect of Capital Adequacy Ratio (CAR), Liquidity and Operational Efficiency To Profitability Banking Company Registered on the IDX. Management Journal, volume 01, number 01 September 2012.

7. Donald E. Kieso, Jerry J. Weygantt, and Terry D. Warfield. 2005. Intermediate Accounting. 11th Edition. Revised Edition. Jakarta: Publisher Erlangga.

8. Erni Nuraeni. 2011. Effect of Cash Flow and Working Capital on Profitability. Essay. Indonesian Computer University.

9. Fred, Skousen K. 2009. Financial Accounting: Concepts and Applications. Jakarta: Salemba.

10. Indonesian Accountants Association. 2012. Financial Accounting Standards. The first print of June 2012 Jakarta: IAI.

11. Imam Ghozali. 2009. Application of Multivariate Analysis with the SPSS program. Print IV April 2009. Semarang: Diponegoro University Publishing Agency.

12. Inta Budi Setyanusa. 2013. Influence of Liquidity and Capital Structure on Profitability (Study of Cases in Manufacturing Companies in the Food Sector \& Baverage Registered on the Indonesia Stock Exchange 2007-2012). Essay. Indonesian Computer University.

13. Jacek Jaworski and Leszek Czerwonka. 2018. Relationship Between Profitability and Liquidity of Enterprises Listed on Warsaw Stock Exchange. Journal. Poland: WSB University.

14. J. Supranto. 2014. Theory and Application of Statistics. Volumes 1 and 2. Editions to VII. Jakarta: Erlangga Publisher. Khemala Febriani Mardhika. 2012, Influence Rotation Inventory and Cash Flow to Profitability at PT. Kimia Farma (Persero) Tbk. Essay. Plant Bandung.

15. Lisna Riany Silaen. 2012. Effect Analysis of Liquidity Ratio on Profitability at PT. Hilon Sumatera Medan. Essay. University of Northern Sumatra.

16. Munawir. 2007. Analysis of Financial Statements. Yogyakarta: Liberty.

17. Rena Kurniawati. 2012. Effect of Net Cash Flow on Liquidity and Its Impact on Profitability. Essay. Siliwangi University.

18. Rudianto. 2013. Management accounting. Jakarta: Erlangga Publisher.

19. Safdar, Muhammad Zulkarnaen, et al. 2015. What Does Matter? Liquidity or Profitability: A Case of Sugar Industry in Pakistan. Journal. Kuala Lumpur: University of Technology Malaysia.

20. Shopi Guspiati. 2008. Effect of Liquidity Ratio on Profitability. Essay. State Islamic University of Sunan Kalijaga Yogyakarta. 
21. Sofyan Syafri Harahap. 2010. Accounting Theory. Jakarta: Raja Grafindo Persada.

22. Sri Nurdianti. 2013. Effect of Liquidity on Profitability. Essay. Gunadarma University.

23. Sugiyono. 2010. Statistics for Research. Bandung: Alfabeta.

24. Suriani Ginting. 2012. Journal of Microscopic Economics of Volume 2.

25. Sutarti and Adi Sulaeman. 2011. Effect of Operating Cash Flow on Company Profit Growth Case Study on PT Multi Manunggal (PT Indofood Sukses Makmur Tbk and PT Unilever Indonesia Tbk). Ranggading Scientific Journal Volume 11, no. 2, October 2011: $117-125$.

26. Sutrisno. 2009. Financial Management. Yogyakarta: Ekonosia.

27. Suwardy. 2011. IFRS Financial Accounting. Volume 8 edition 2. Jakarta: Erlangga Publisher.

28. Wael Mostafa. 2015. The incremental value of the relevance of cash flows and earnings affected by their extremity. Journal. Cairo: Ain Shams University.

29. Wild, John J. 2005. Financial Statement Analysis. Issue 8 Book Two. Jakarta: Salemba Empat. 